\title{
Experimental studies on an indigenous coconut shell based activated carbon suitable for natural gas storage
}

\author{
SATYABRATA SAHOO and M RAMGOPAL* \\ Department of Mechanical Engineering, Indian Institute of Technology Kharagpur, Kharagpur 721302, India \\ e-mail: satyabrata111sahoo4@gmail.com; ramg@mech.iitkgp.ernet.in
}

MS received 20 April 2015; revised 21 August 2015; accepted 11 November 2015

\begin{abstract}
Experimental studies are carried out to characterize an indigenous, coconut shell based, activated carbon suitable for storage of natural gas. Properties such as BET surface area, micropore volume, average pore diameter and pore size distribution are obtained by using suitable instruments and techniques. An experimental setup is developed to estimate the equilibrium methane adsorption capacity and adsorption/desorption kinetics. The experimental isothermal uptake data is used to fit four different isotherm models. Using the constants obtained for the D-A isotherm model the variation of heat of adsorption and adsorbed phase specific heat with equilibrium pressure and temperature are obtained. Similarly Henry's Law coefficients, important at low pressure and low uptake regime are also obtained. Finally using the kinetic data and a linear driving force model, constants in the kinetic equation are obtained. Results show that the indigenous material used in this study offers reasonably high natural gas storage capacity and fast kinetics and is suitable for adsorbed natural gas (ANG) applications. It is expected that this study will be useful in the design and development of ANG systems based on this indigenous material.
\end{abstract}

Keywords. Activated carbon; natural gas storage; material characterization; isotherm data; kinetics.

\section{Introduction}

Natural gas (NG) as an alternate fuel is attractive due to its less polluting nature [1]. From compactness, safety, design flexibility and economics points of view, storing NG in the adsorbed phase using adsorbents such as activated carbon is better compared to other modes of storage, e.g. in compressed natural gas $(\mathrm{CNG})$ or liquefied natural gas (LNG) storage [2-7]. However, for successful use of adsorbed natural gas or ANG technology, it is essential to develop adsorbents which are highly micro-porous with high surface area. Many researchers have carried out experimental studies to predict the adsorption capacity as well as micro-structure characteristics of different activated carbons such as MAXSORB, AX21, Norit RGM1 and their composites [5, 8-13]. Significant effort has been made to improve the packing density by preparing composite adsorbents $[2,3,14]$. Studies show that currently the MAXSORB family yields highest storage as well as delivery capacity and match the DOE standards [11, 15]. However, as mentioned in the literature MAXSORB is developed from petroleum coke which is a fossil product. Also MAXORB is not locally available. Hence there is a need for developing new adsorbent materials from locally

*For correspondence available and inexpensive materials such as agricultural waste. In this paper results obtained from experimental studies on material characteristics, adsorption isotherms and kinetics of a coconut shell based activated carbon are presented. It is expected that these results will promote large scale use of the indigenous material that is also environment friendly and inexpensive.

\section{Experimental studies}

\subsection{Materials used}

2.1a Activated carbon: Granular type activated carbon "IndoCarb GC D612" supplied by ICC Indo German Carbons limited, Kerala, India was used as the adsorbent for this experimental study. The sample is developed from coconut shell by steam activation. The particle size of the adsorbent is $6 \times 12$ US mesh with moisture content $4 \%$ and apparent density $523\left(\mathrm{~kg} / \mathrm{m}^{3}\right)$ as mentioned by the supplier.

2.1b Methane: Ultrapure methane with $99.99 \%$ purity supplied by Indian refrigeration stores, Kolkata, India, is used as the adsorbate for this study. Helium gas from the same supplier is used for calibration of the dead volume and for leak testing. 


\subsection{Characterization of the adsorbent}

The structural property of the activated carbon calcined at $120^{\circ} \mathrm{C}$ for overnight was carried out by XRD using an excitation wavelength of $0.154 \mathrm{~nm}$ (Cu target). As shown in figure 1, it has three broad peaks which nearly resemble the graphite peaks of PDF no 01-075-2078 having Rhombohedral structure with space group R-3m (166). The peaks are approximately at $23.9,43.8$ and 80.3 positions (20), which correspond to the planes (111), (100) and (210) respectively. Although these XRD peaks confirm the charcoal characteristics, due to the nanoscale of powder broad peaks are observed.

The surface morphologies of the adsorbent were examined by scanning electron microscope (SEM). The SEM pictures are shown in figures 2 and 3. From these SEM images it can be inferred that the material under consideration is

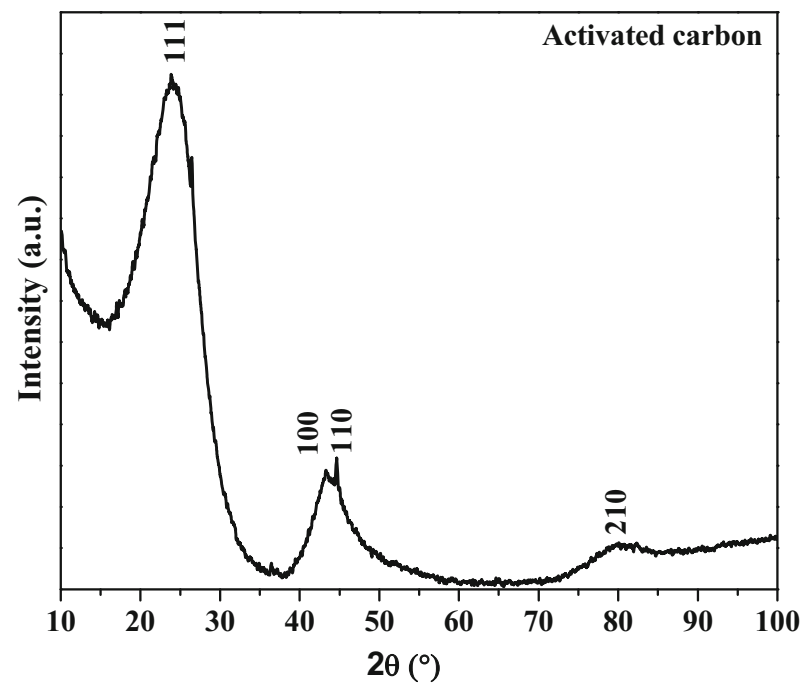

Figure 1. XRD analysis of coconut shell activated carbon.

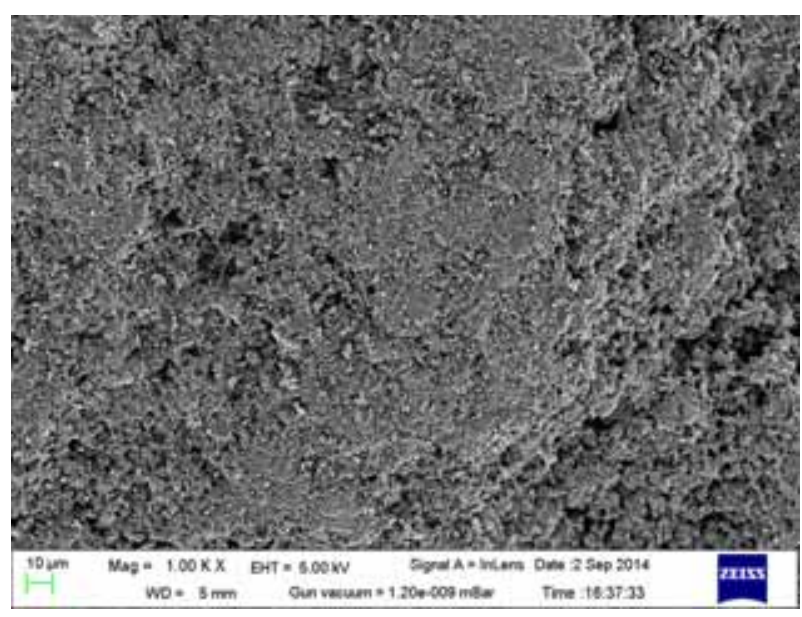

Figure 2. SEM photograph of coconut shell activated carbon sample at magnification of $1 \mathrm{KX}$.

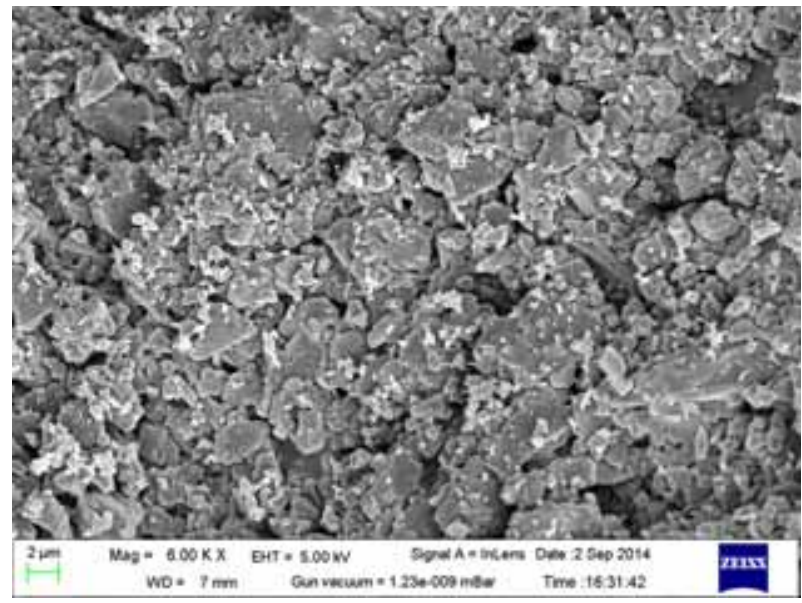

Figure 3. SEM photograph of coconut shell activated carbon sample at magnification of $6 \mathrm{KX}$.

chemically pure and highly porous with varying particle sizes, thus confirming its suitability for NG storage.

\subsection{Measurement of adsorption properties}

The porous properties such as Brunauer-Emmett-Teller (BET) surface area, the pore size and the pore volume of the activated carbon sample are listed in table 1. The structural properties were measured using Autosorb (Quantachrome instrument version 3.0) machine from the $\mathrm{N}_{2}$ adsorption data. The adsorption was performed at $77.35 \mathrm{~K}$.

The pore size distribution (PSD) of the activated sample has been found by the density functional theory (DFT) method from adsorption isotherm data of $\mathrm{N}_{2}$ at $77.35 \mathrm{~K}$ onto activated carbon sample using Autosorb machine (Quantachrome instrument version 3.0). The method is based on molecular model for nitrogen adsorption in porous carbon. The experimental adsorption isotherm measured on a porous sample is the aggregate of the isotherms for individual pores that make the pore structure of the solid. Mathematically the experimental isotherm is the integral of the single pore isotherm multiplied by the pore size distribution. For slit shaped pore the generalised adsorption isotherm equation can be written as [16]:

$$
N(P)=\int_{w_{\min }}^{w_{\max }} f(w) \rho(P, w) \mathrm{d} w
$$

where $N(P)$ is the number of moles adsorbed at pressure $P$, $\rho(P, w)$ is the molar density of nitrogen at pressure ' $P$ ' and pore width ' $w$ ' and $w_{\min }$ and $w_{\max }$ are the widths of the smallest and largest pores. The pore size distribution, $f(w)$ is the distribution of the pore volumes as a function of pore width. The pore size distribution is then derived by solving the generalized adsorption isotherm equation (1) for 
Table 1. Structural properties of the activated carbon sample.

\begin{tabular}{lccr}
\hline Activated carbon sample & Surface area $\left(\mathrm{m}^{2} / \mathrm{g}\right)$ & Total pore volume $\left(\mathrm{cm}^{3} / \mathrm{g}\right)$ & Average pore diameter $(\AA)$ \\
\hline IndoCarb GC D612 & 1032.26 & 0.436 & 17.29 \\
\hline
\end{tabular}

$f(w)$ numerically using a fast non-negative least square algorithm. Quantachrome instrument with built-in data analysis software allows micro/mesopore analysis of different micro and mesopore materials. PSD is usually represented either in differential form or in cumulative form. The differential method plots the change in pore volume divided by the change in pore radius as a function of pore radius. In effect it shows a representation of the fraction of pore volume at a given pore size. The cumulative plot shows how the total pore volume varies as pore radius increases. Even though both these methods are useful, in the present study the differential method is employed. To obtain a more realistic PSD appearance the DFT reports (pore volume, $\mathrm{cm}^{3} / \mathrm{g}$ ) have been derived by normalizing the pore volume to the pore size interval (differential volume $\left.\mathrm{d} V / \mathrm{d} r, \mathrm{~cm}^{3} / \AA / \mathrm{g}\right)$. For the sample the PSD curve as presented in figure 4 shows few peaks in the micro-pore region. The pore volumes of $0.479,0.098,0.047,0.1294$, 0.22 and $0.044 \mathrm{~cm}^{3} / \AA / \mathrm{g}$ occur at half pore width of 2.71 , $3.25,3.824,4.49,5.14$ and $5.88 \AA$ respectively and pore volumes are negligible in the mesopore region $(>10 \AA$ half pore width) which confirms that the coconut shell sample is micro-porous.

\subsection{Test facility for generating sorption isotherm and kinetic data}

An experimental test rig is developed for generating isotherm and kinetic test data of the indigenous activated carbon and methane pair. Figure 5 shows the schematic diagram of the experimental rig which consists of an adsorption cell (reactor) and storage cylinder made of stainless steel (SS 304). The internal volumes of the adsorption cell and storage cylinder are $57 \mathrm{ml}$ and 6,000 ml respectively.

The adsorption cell filled with the activated carbon sample is completely submerged in a thermostatic bath (Julabo F25) and is connected to the storage tank using 1/4" nominal stainless steel plumbing and set of Swagelok fittings (Valves $\left(\mathrm{V}_{1}, \mathrm{~V}_{2}, \mathrm{~V}_{3}, \mathrm{~V}_{4}, \mathrm{~V}_{5}\right)$ T's and reducers). The thermostatic bath is used to maintain nearly isothermal condition in the reactor at the set temperature. The storage cylinder is connected to the $\mathrm{CH}_{4}$ and He cylinders through Valves $\left(\mathrm{V}_{1}\right.$ and $\left.\mathrm{V}_{5}\right)$ and regulators. A porous filter of $12 \mathrm{~mm}$ diameter made of stainless steel mesh $(100 \mu \mathrm{m})$ is placed at the centre of the reactor to facilitate flow of NG. The top portion of the bed is covered with filter paper to avoid carry-over of the adsorbent particles during evacuation and desorption process. Three copper constantan $\mathrm{K}$

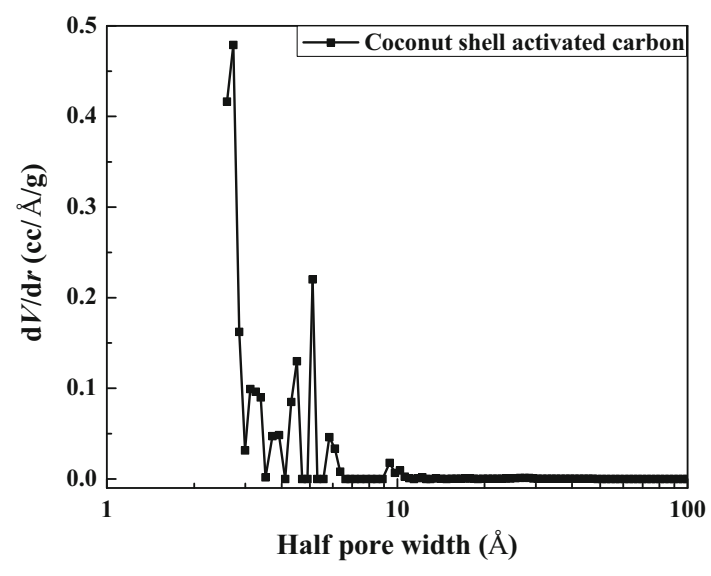

Figure 4. Pore size distribution of the activated carbon sample.

type thermocouples are placed at three different positions of the adsorption cell to measure the temperature of the adsorbent bed at three different locations. One thermocouple is also connected to the storage cylinder to record the temperature of the gas in the storage cylinder. Two pressure transducers $\left(\mathrm{P}_{\mathrm{T} 1}, \mathrm{P}_{\mathrm{T} 2}\right.$, WIKA instruments India Pvt. Ltd, range $0-60$ bar, uncertainty $\pm 25 \%$ of full scale) are used to monitor the pressure in the storage cylinder and the adsorption cell respectively. A data acquisition system (Yokogawa, MW 100) interfaced with the computer is used to store the pressure and temperature data. A vacuum pump is connected to the storage as well as adsorption cell to evacuate the system whenever required through the valves $\mathrm{V}_{3}$ and $\mathrm{V}_{4}$ respectively.

\subsection{Experimental procedure}

The adsorbent reactor is filled with $(30 \pm 1 \mathrm{~g})$ activated carbon and placed in the thermostatic bath. Then complete system is made leak-proof after testing for leaks using high pressure helium gas. Then the reactor with the adsorbent is heated and evacuated at $95^{\circ} \mathrm{C}$ for $8 \mathrm{~h}$ to make the adsorbent moisture free. Then the entire system is purged with helium and is evacuated again.

2.5a Helium calibration: The dead volume is estimated using helium gas. Helium gas is charged into the storage tank keeping valves $V_{2}$ and $V_{3}$ in closed position and the pressure and temperature of the storage tank are recorded using the pressure transducer $\left(\mathrm{P}_{\mathrm{T} 1}\right)$ and thermocouple $\mathrm{T}_{4}$. Then the valve between the reactor and storage tank $\left(\mathrm{V}_{2}\right)$ is opened for few seconds and closed. After the pressure gets 


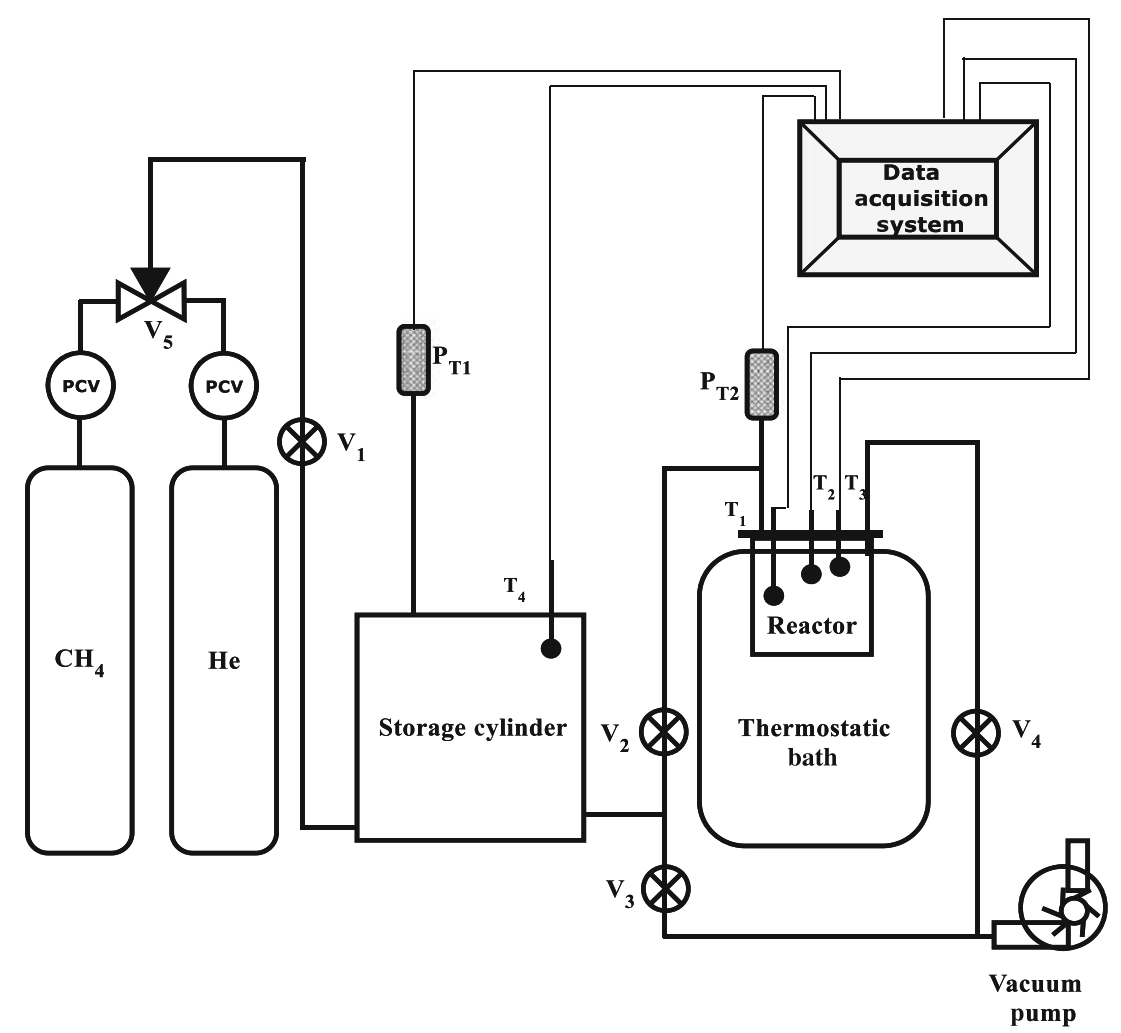

Figure 5. Schematic of the experimental setup. (PCV: Pressure control valve, $\left(V_{1}, V_{2}, V_{3}, V_{4}, V_{5}\right)$ : Valves, $\left(T_{1}, T_{2}, T_{3}, T_{4}\right.$ ): Thermocouples, $\mathrm{P}_{\mathrm{T} 1}$ and $\mathrm{P}_{\mathrm{T} 2}$ : Pressure transducers).

stabilized both the storage tank and sorbent reactor pressure as well temperature are recorded and the dead volume is calculated using the following equation:

$V_{\mathrm{st}}\left(\rho_{\mathrm{He}}\left(P_{\mathrm{st}, \mathrm{i}}, T_{\mathrm{st}, \mathrm{i}}\right)-\rho_{\mathrm{He}}\left(P_{\mathrm{st}, \mathrm{f}}, T_{\mathrm{st}, \mathrm{f}}\right)\right)=V_{\text {dead }}\left(\rho_{\mathrm{He}}\left(P_{\text {rea }}, T_{\text {rea }}\right)\right)$

where the density of helium $\left(\rho_{H e}\right)$ as a function of temperature and pressure is taken from NIST Standard Reference Database 23, Version 9.0. Using the above procedure the dead volume is found to be $52.6 \mathrm{ml}$.

2.5b Methane isotherm measurements: Once the dead volume is calculated the system is completely evacuated at $95^{\circ} \mathrm{C}$ for $8 \mathrm{~h}$ to remove the residual gases, if any. Prior to supply of the methane gas the reactor is maintained at the set temperature by the thermostatic bath. Then storage tank is charged with methane from the methane cylinder keeping the valves $\left(V_{2}\right.$ and $\left.V_{3}\right)$ between the reactor and storage tank closed and the initial pressure and temperature of the gas in the storage tank are measured using pressure transducer $\left(\mathrm{P}_{\mathrm{T} 1}\right)$ and the thermocouple $T_{4}$. Then the valve $\left(V_{2}\right)$ between the storage tank and reactor is opened for few seconds and closed. After the closure of the valve $\mathrm{V}_{2}$ again the gas pressure and temperature in the storage tank are recorded. During this period the reactor is kept in the thermostatic bath at set temperature. After the valve $\mathrm{V}_{2}$ is closed the pressure in the reactor starts dropping due to gas adsorption and the reactor temperature and pressure get stabilizes after few hours. When no change is observed for nearly one hour, the bed is assumed to be in equilibrium. The corresponding pressure is recorded using the transducer $\mathrm{P}_{\mathrm{T} 2}$. The temperature of the sorbent bed is measured at three different locations and mean of the three is taken as the equilibrium temperature. Next the thermostatic bath set temperature is changed and the bed is allowed to reach equilibrium state at some other pressure and set temperature without opening the valve $\mathrm{V}_{2}$. In this way a set of readings are taken for different set temperatures. Then the storage tank is charged to a higher pressure and the valve between the reactor and storage tank are opened again for few second and closed and the bed is allowed to reach equilibrium at higher pressure. The above process is repeated for different set temperatures. For each of these cases, the adsorbed amount is calculated using the following equation.

$$
\begin{aligned}
& V_{s t}\left(\rho_{\text {Me }}\left(P_{s t, i}, T_{s t, i}\right)-\rho_{M e}\left(P_{s t, f}, T_{s t, f}\right)\right) \\
& \quad=V_{\text {dead }}\left(\rho_{\text {Me }}\left(P_{\text {rea }}, T_{\text {rea }}\right)\right)+m_{s} a_{e q}
\end{aligned}
$$

where ' $m_{\mathrm{s}}$ ' is the mass of the adsorbent and ' $a_{e q}$ ' is the equilibrium adsorption capacity per $\mathrm{kg}$ of the adsorbent. Since the experimental temperature range of $5-50^{\circ} \mathrm{C}$ is not very high, the expansion due to temperature variation is neglected.

2.5c Measurement of kinetics of methane adsorption/desorption: The kinetic study was done for charging at $5^{\circ} \mathrm{C}$ 
and discharge at $50^{\circ} \mathrm{C}$. During charging process, initially the reactor is completely evacuated and regenerated at $95^{\circ} \mathrm{C}$ for about $8 \mathrm{~h}$ to remove the residual gases. After the evacuation and regeneration process the sorbent bed is maintained at $5^{\circ} \mathrm{C}$ by setting the temperature in the thermostatic bath. Then the storage tank is charged up to 1.5 $\mathrm{MPa}$ keeping the valve $\mathrm{V}_{2}$ closed. After the pressure in the storage tank getting stabilized the valve $V_{2}$ is opened. As soon as the valve $\mathrm{V}_{2}$ is opened the pressure in the storage tank starts dropping due to adsorption of gas onto the activated carbon. The variation of the storage tank pressure and temperature is recorded for every $1 \mathrm{~s}$ time interval. The recording is continued till no variation in the storage tank pressure is observed. After the adsorption study the valve $\mathrm{V}_{2}$ is closed and storage cylinder is evacuated to a gauge pressure of $-92 \mathrm{kPa}$ by opening the valve $\mathrm{V}_{3}$ and switching on the vacuum pump. Then the adsorbent in the reactor is heated up to $50^{\circ} \mathrm{C}$ by changing the set temperature of thermostatic bath. Once the reactor reaches equilibrium at $50^{\circ} \mathrm{C}$ the valve between the reactor and the storage tank is opened. Then the rise of the storage tank pressure is recorded for every $1 \mathrm{~s}$ interval till no change is observed. From the gas pressure and temperature variation data of the storage tank, the adsorption rate is obtained using following equations.

$$
\begin{aligned}
& \left(\frac{\mathrm{d} a}{\mathrm{~d} \tau}\right)_{d i s}=\frac{V_{t}}{m_{s}}\left(\frac{\rho\left(P_{i+1}, T_{i+1}\right)-\rho\left(P_{i}, T_{i}\right)}{t_{i+1}-t_{i}}\right) \\
& \left(\frac{\mathrm{d} a}{\mathrm{~d} \tau}\right)_{c h a}=\frac{V_{t}}{m_{s}}\left(\frac{\rho\left(P_{i}, T_{i}\right)-\rho\left(P_{i+1}, T_{i+1}\right)}{t_{i+1}-t_{i}}\right)
\end{aligned}
$$

where $P_{i}, T_{i}$ and $P_{i+1}, T_{i+1}$ are the pressures and temperatures of the storage tank at a particular time instance (i) and next time instance $(i+1)$, respectively. ' $V{ }_{t}$ ' is the total volume, comprising of reactor as well as the storage tank and $m_{\mathrm{s}}$ is the mass of the adsorbent taken inside the reactor (adsorption cell).

\section{Results and discussion}

\subsection{Adsorption isotherm models}

Four different isotherm models, Dubinin-Astakhov (D-A), Dubinin-Radushkevich (D-R), Langmuir and Toth isotherm models have been used to correlate equilibrium adsorption uptake values. Among the different models, the Langmuir model is the simplest one. The Langmuir model describes the monolayer type of adsorption and the surface of the adsorbents is assumed to be homogenous with constant heat of adsorption over all sites. Localized adsorption on the adsorbent surface with one molecule or atom at each site is the central assumption of the Langmuir model. The Langmuir model is given by Wang et al [17]:

$$
\frac{a_{e q}}{C_{o}}=\frac{k_{o} \exp \left(\Delta H_{a d s} / R T\right) P}{1+k_{o} \exp \left(\Delta H_{a d s} / R T\right) P}
$$

where $C_{o}$ is the saturated amount adsorbed, $P$ is the equilibrium pressure, $k_{o}$ is the equilibrium constant, $H_{\mathrm{ads}}$ is the heat of adsorption and $R$ is the gas constant. Langmuir model does not give good fit for uptake at high pressure. The Toth model gives better fit for heterogeneous adsorbent such as activated carbon both for high and low pressure ends. The expression for the Toth model can be represented by Wang et al [17]:

$$
\frac{a_{e q}}{C_{o}}=\frac{k_{o} \exp \left(\Delta H_{a d s} / R T\right) P}{\left[1+\left\{k_{o} \exp \left(\Delta H_{a d s} / R T\right) P\right\}^{t}\right]^{1 / t}}
$$

The parameter $t$ takes care of the structural heterogeneity of the adsorbent material. The Toth model resembles the Langmuir model when the heterogeneity parameter $(t)$ becomes unity.

The most suitable model for micropore adsorption was proposed by Dubinin and Astakhov, which is the more generalised version of the Dubinin and Radushkevich (DR) model. The D-A model allows for surface heterogeneity and can also be extended for higher pressures. The expression for D-A is as follows [18]:

$$
W=W_{o} \exp \left[-\left(\frac{A}{E}\right)^{n}\right]
$$

' $A$ ' is the adsorption potential, $W$ is the amount of adsorbate uptake in $\mathrm{m}^{3} / \mathrm{kg}$ and $W_{o}$ is the limiting uptake and is considered to correspond to the micropore volume of the adsorbent, $E$ is the characteristic energy of the adsorption system and $n$ is the structural heterogeneity parameter. The adsorption potential $A$ is the isothermal work of compression of unit mass of adsorbate vapour from pressure $P$ to $P_{\text {sat }}$. So 'A' is given by Ozawa et al [18]:

$$
A=R T \ln \left(\frac{P_{\text {sat }}}{P}\right)
$$

Using the D-A isotherm model the equilibrium adsorption uptake per $\mathrm{kg}$ of the adsorbent can be expressed as [18]:

$$
a_{e q}=\frac{W_{o}}{v_{a}} \exp \left[-\left(\frac{R T \ln \left(\frac{P_{s a t}}{P}\right)}{E}\right)^{n}\right]
$$

where $v_{a}$ is the specific volume of the adsorbed phase and is estimated using the following formula. Ozawa et al [18]:

$$
v_{a}=v_{b} \exp \left[\alpha\left(T-T_{b}\right)\right]
$$

where $v_{b}$ is the specific volume of saturated liquid at normal boiling point $T_{b}$ and $\alpha$ is the thermal expansion coefficient of superheated liquid, which is assumed as [11]: 


$$
\alpha=\frac{1}{v_{a}}\left(\frac{\partial v_{a}}{\partial T}\right)_{p} \approx \frac{1}{T} .
$$

The pseudo saturated pressure of the supercritical gas is calculated using the following expression [18]:

$$
P_{s a t}=\left(\frac{T}{T_{c r}}\right)^{2} P_{c r}
$$

where $P_{\mathrm{cr}}$ and $T_{\mathrm{cr}}$ are the critical pressure and temperature of the adsorbate.

The $\mathrm{D}-\mathrm{R}$ model is a more restricted version of the $\mathrm{D}-\mathrm{A}$ which does not allow the variation of the heterogeneity parameter $n$ depending on the adsorbent and adsorbate pair and the equation is given by Ozawa et al [18]:

$$
a_{e q}=\frac{W_{o}}{v_{a}} \exp \left[-\left(\frac{R T \ln \left(\frac{P_{s a t}}{P}\right)}{E}\right)^{2}\right]
$$

Figures 6 and 7 show both experimental and predicted adsorption uptake of methane onto the coconut shell based activated carbon using D-A and D-R models respectively. The observations are taken for the temperature range of $5-50^{\circ} \mathrm{C}$ and pressures up to $2 \mathrm{MPa}$. The non-linear regression analysis is done using Engineering Equation Solver (EES professional V9.158) to find the constants in the above-mentioned models. The constants of the D-A and $\mathrm{D}-\mathrm{R}$ model are tabulated in table 2. The figures show that the models give good fit with a maximum error of $10 \%$.

Figures 8 and 9 show the comparison between experimental uptake and the predicted values using Toth and Langmuir isotherm models. The results are seen to match within a maximum error of $10-15 \%$. The constants of the model are tabulated in table 3.

The Langmuir and Toth models provide a constant value for the heat of adsorption considering homogeneous surface structure of the adsorbent. For energetically homogenous

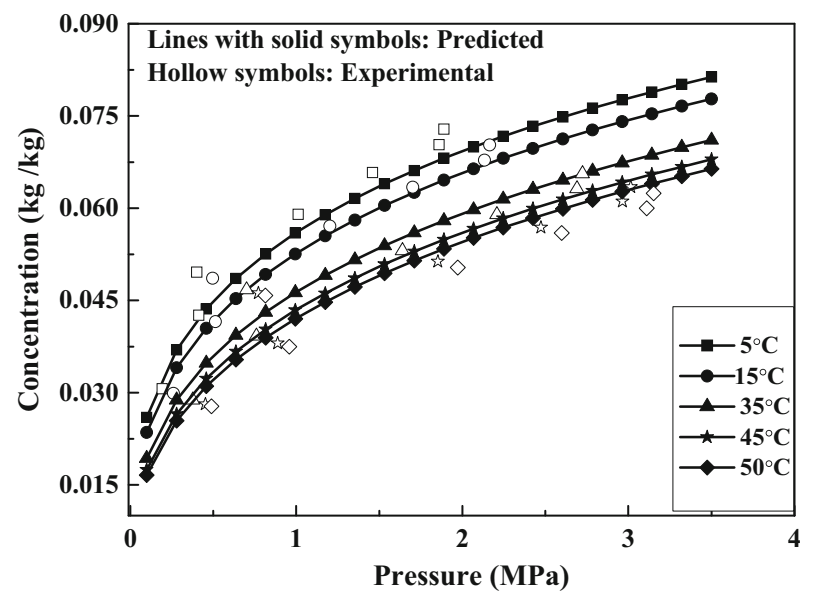

Figure 6. Experimental and predicted D-A adsorption isotherms.

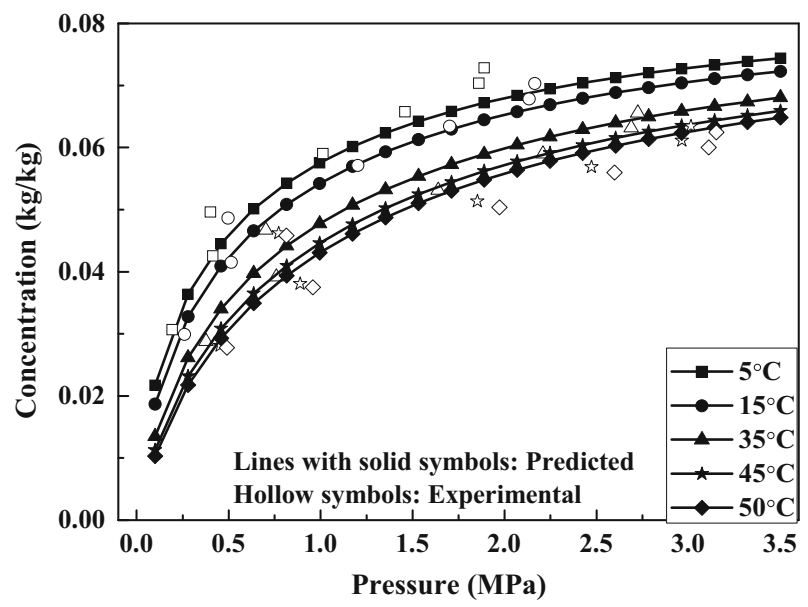

Figure 7. Experimental and predicted D-R adsorption isotherm.

Table 2. Adsorption parameters for the D-A and D-R isotherm model.

\begin{tabular}{lcc}
\hline & \multicolumn{2}{c}{ IndoCarb GC D612 } \\
\cline { 2 - 3 } Parameters & $\mathrm{D}-\mathrm{A}$ isotherm & $\mathrm{D}-\mathrm{R}$ isotherm \\
\hline$W_{o}\left(\mathrm{~m}^{3} / \mathrm{kg}\right)$ & $0.4463 \times 10^{-3}$ & $0.3417 \times 10^{-3}$ \\
$E(\mathrm{~J} / \mathrm{mol})$ & 7998 & 9299 \\
$n$ & 1.163 & 2 \\
$R^{2}$ value for the & 0.928 & 0.931 \\
$\quad$ regression analysis & & \\
\hline
\end{tabular}

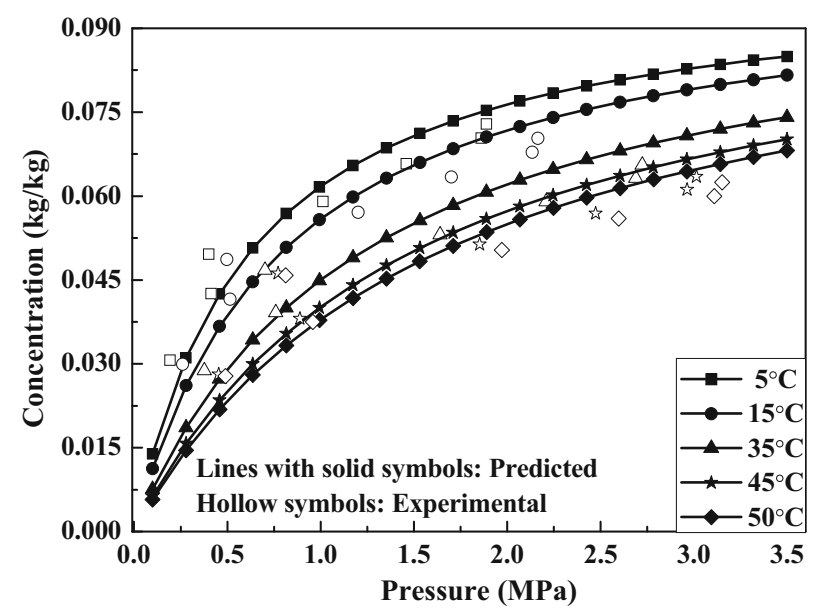

Figure 8. Experimental and predicted Langmuir adsorption isotherm.

adsorption sites there is absence of interaction between adsorbed molecules resulting in constant heat of adsorption. However for heterogeneous surface structure of the adsorbent with number of patches having different energy levels or when the interaction among the adsorbed molecules cannot be neglected, the heat of reaction varies with surface 


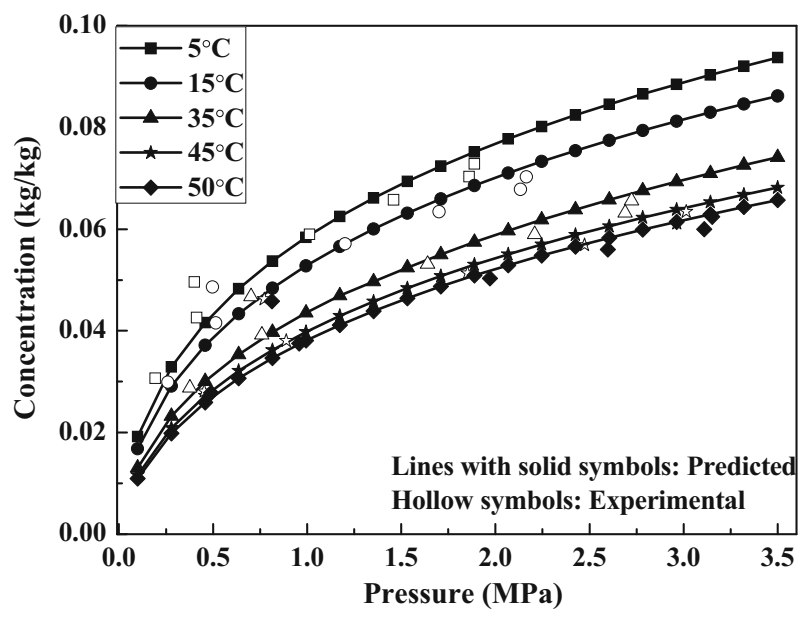

Figure 9. Experimental and predicted Toth adsorption isotherm.

Table 3. Adsorption parameters for Langmuir and Toth isotherm model.

\begin{tabular}{|c|c|c|}
\hline \multirow[b]{2}{*}{ Parameters } & \multicolumn{2}{|c|}{ IndoCarb GC D612 } \\
\hline & $\begin{array}{l}\text { Langmuir } \\
\text { isotherm }\end{array}$ & $\begin{array}{l}\text { Toth } \\
\text { isotherm }\end{array}$ \\
\hline$C_{o}(\mathrm{~g} / \mathrm{g})$ & 0.1 & 0.4991 \\
\hline$k_{o} \times 10^{3} \mathrm{MPa}^{-1}$ & 1.5 & 4 \\
\hline$\Delta H_{\mathrm{ads}} / \mathrm{R}(\mathrm{K})$ & 1941 & 1929 \\
\hline$t$ & - & 0.2484 \\
\hline $\begin{array}{l}R^{2} \text { value for the regression } \\
\text { analysis }\end{array}$ & 0.814 & 0.889 \\
\hline
\end{tabular}

coverage. Hence the heat of adsorption under these conditions becomes a function of equilibrium adsorption uptake and an indirect function of equilibrium pressure and temperature. Using the Clausius-Clayperon equation and D-A isotherm model the expression for temperature and concentration dependent heat of adsorption can be obtained as

$$
\begin{aligned}
\Delta H_{a d s}= & Z\left[E\left[\left(\ln \frac{W_{o}}{a_{e q} v_{a}}\right)^{1 / n}+\frac{\alpha T}{n}\left(\ln \frac{W_{o}}{a_{e q} v_{a}}\right)^{1-n / n}\right]\right. \\
& \left.+2 R_{u} T\right] / M .
\end{aligned}
$$

Similarly the expression for the specific heat of the adsorbed phase is given as

$$
C_{P, a}=C_{P, g}(P, T)+\frac{\alpha^{2}(1-n)}{n^{2}} \frac{E T}{M}\left(\ln \left(\frac{W_{o}}{a_{e q} v_{a}}\right)\right)^{\frac{1-2 n}{n}}-2 R
$$

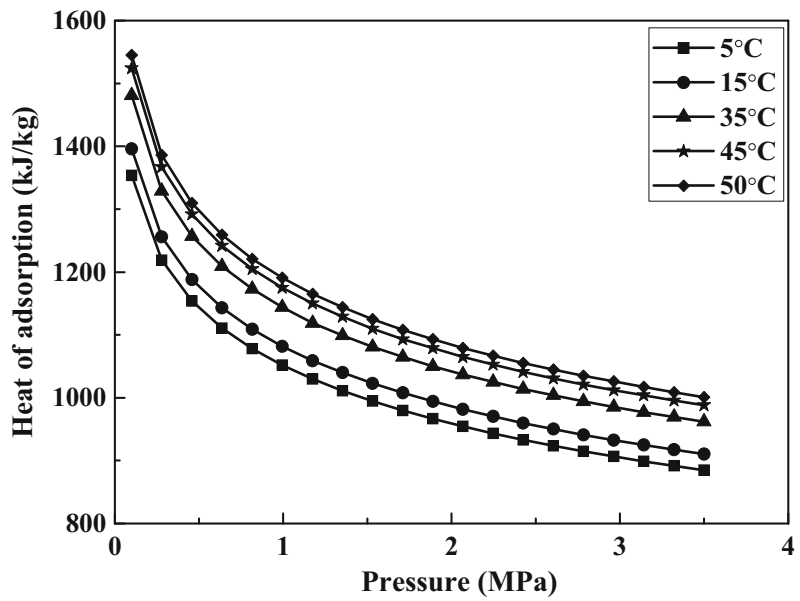

Figure 10. Variation heat of adsorption with equilibrium pressure and temperature.

From Eqs. (15) and (16) it is clear that the heat of adsorption as well as the specific heat of the adsorbed phase are inversely related to equilibrium adsorption capacity. So with increase in bed pressure as the equilibrium adsorption uptake increases, the heat of adsorption and the specific heat of the adsorbed phase reduce.

Figure 10 shows the variation of the heat of adsorption with equilibrium pressure and temperature for the given material. At a low pressure and high temperature, the equilibrium adsorption up take $a_{\mathrm{eq}}$ is less. As the heat of adsorption is inversely proportional to the equilibrium uptake, for low pressure and high temperature the heat of adsorption is high and low at high pressure and low temperature. Figure 11 shows the variation of the adsorbed phase specific heat with equilibrium pressure and temperature. Figure shows that with increase in equilibrium pressure equilibrium concentration increases resulting decrease in adsorbed phase specific heat. Adsorbed phase specific heat is the difference between the gaseous phase specific heat and differential of heat of adsorption with respect to temperature at constant concentration. So similar to the heat of adsorption, specific heat also shows a decreasing trend with increase in pressure.

The Henry's region is the low pressure and low uptake regime. As both the Langmuir and Toth isotherm works well at low and high end of the pressure ranges, they do possess the correct Henry law behaviour. Therefore the temperature dependent Henry's law coefficient $\left(K_{H}\right)$ is determined using the following expression [11].

$$
K_{H}=k_{o} \exp \left(\frac{\Delta H_{a d s}}{R T}\right) .
$$

The coefficient for the activated carbon at different temperatures is listed in table 4 . The table clearly shows that the $K_{H}$ value and hence the amount of gas adsorbed/ desorbed decreases as the temperature increases. 


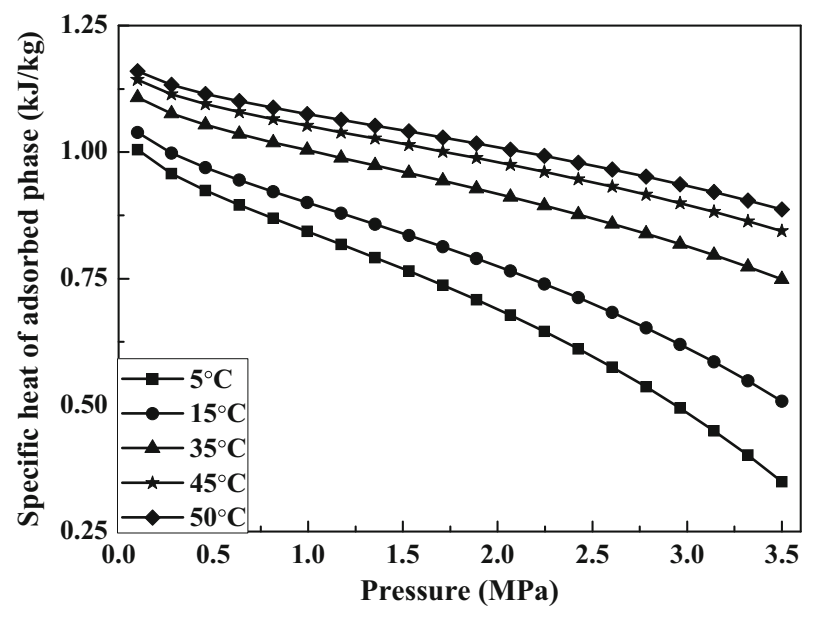

Figure 11. Variation of adsorbed phase specific heat with equilibrium pressure and temperature.

Table 4. The Henry's Law coefficients $K_{H}(1 / \mathrm{MPa})$.

\begin{tabular}{|c|c|c|}
\hline \multirow[b]{2}{*}{$\begin{array}{l}\text { Temperature } \\
\left({ }^{\circ} \mathrm{C}\right)\end{array}$} & \multicolumn{2}{|c|}{$\begin{array}{c}\text { IndoCarb GC D612 } \\
\text { Henry's law coefficient }\left(\mathrm{MPa}^{-1}\right)\end{array}$} \\
\hline & $\begin{array}{l}\text { Calculated from } \\
\text { Langmuir isotherm }\end{array}$ & $\begin{array}{l}\text { Calculated from Toth } \\
\text { isotherm }\end{array}$ \\
\hline 5 & 1.61 & 4.115 \\
\hline 15 & 1.263 & 3.235 \\
\hline 25 & 1.008 & 2.584 \\
\hline 35 & 0.8159 & 2.095 \\
\hline 45 & 0.6694 & 1.72 \\
\hline 50 & 0.6091 & 1.566 \\
\hline
\end{tabular}

\subsection{Theoretical models of adsorption kinetics}

The linear driving force (LDF) model was originally proposed by Glueckauf and Coates [19]. The model is frequently used for modeling the transient behaviour of adsorption and desorption of pure or gaseous mixtures into an adsorbent because it is analytical, simple and physically consistent [2024]. So in the present study the LDF model is used to describe the intra particle diffusion of methane into activated carbon. According to the model the rate of adsorption is linearly proportional to the difference between the equilibrium uptake $a_{e q}$ and instantaneous uptake $a$. For this study the equilibrium uptake $a_{\mathrm{eq}}$ at the corresponding pressure and temperature is calculated using the D-A isotherm model and the constants for the model are taken from table 2. The expression for the LDF model is given as follows [24]

$$
\frac{\mathrm{d} a}{\mathrm{~d} \tau}=K_{s o} \exp \left(-\frac{E_{a}}{R_{u} T}\right)\left(a_{e q}-a\right)
$$

where $E_{a}$ is the energy of activation of the adsorbate and the $K_{\text {so }}$ is the pre-exponential constant. To capture the kinetics of adsorption the same setup was used with slight modification in the procedure. The kinetic study was done

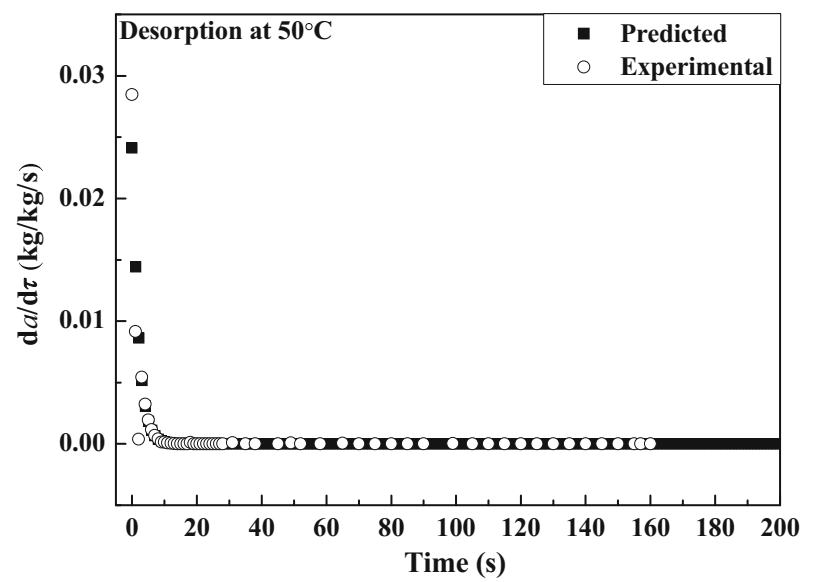

Figure 12. Temporal variation of desorption rate.

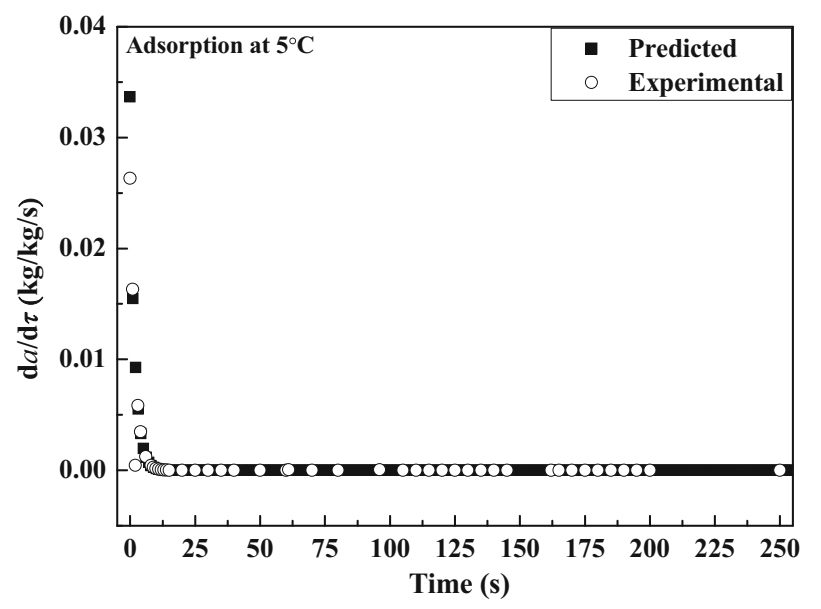

Figure 13. Temporal variation of adsorption rate.

for both charging at $5^{\circ} \mathrm{C}$ and discharge at $50^{\circ} \mathrm{C}$. Figures 12 and 13 show both experimental and predicted variation of desorption and adsorption rate with time for the abovementioned conditions respectively.

Nonlinear regression analysis is done to find out the parameters of the linear driving force model as given in Eq. (18). The constants of the model are listed in table 5.

Table 6 shows a comparative study between the current material and other commercially available materials in terms of storage capacity, internal surface area, average heat of adsorption and characteristic energy, etc. The source materials for different activated carbons are also included in the table.

\subsection{Error analysis of the experimental data}

Uncertainty analysis is carried out with an uncertainty of $3 \mathrm{kPa}$ in pressure measurement and $0.5 \mathrm{~K}$ in the temperature measurement and corresponding uncertainties in the 
Table 5. Adsorption kinetic parameters for liner driving force model (LDF).

\begin{tabular}{lccc}
\hline Activated carbon sample & $E_{\mathrm{a}}(\mathrm{J} / \mathrm{mol})$ & $K_{\text {so }}\left(\mathrm{s}^{-1}\right)$ & $R^{2}$ value for the regression analysis \\
\hline IndoCarb GC D612 & 1500 & 0.8758 & 0.9133 \\
\hline
\end{tabular}

Table 6. Comparative study between different activated carbons [25].

\begin{tabular}{|c|c|c|c|c|c|}
\hline $\begin{array}{l}\text { Activated } \\
\text { carbon }\end{array}$ & $\begin{array}{c}\text { Storage capacity } \\
(\mathrm{g} / \mathrm{kg})\end{array}$ & $\begin{array}{c}\text { Internal surface area } \\
\left(\mathrm{m}^{2} / \mathrm{g}\right)\end{array}$ & $\begin{array}{l}\text { Characteristic energy } \\
\qquad(\mathrm{J} / \mathrm{mol})\end{array}$ & $\begin{array}{l}\text { Average heat of adsorption } \\
\qquad(\mathrm{kJ} / \mathrm{kg})\end{array}$ & $\begin{array}{l}\text { Precursor } \\
\text { material }\end{array}$ \\
\hline Maxsorb III & 256 & 3276 & 4757.3 & 989 & $\begin{array}{c}\text { Petroleum } \\
\text { coke }\end{array}$ \\
\hline AX21 & 169 & 3106 & 5464.1 & 918 & Coconut shell \\
\hline BPL & 69 & 1150 & 7040 & 976 & Coal \\
\hline Norit R1 extra & 89 & 1450 & 7500 & 988 & Peat \\
\hline Chemviron & 90 & 945 & 8684.1 & 1060 & $\begin{array}{c}\text { Bituminous } \\
\text { coal }\end{array}$ \\
\hline $\begin{array}{l}\text { IndoCarb GC } \\
\text { D612 }\end{array}$ & 71 & 1032 & 7998 & 1192 & Coconut shell \\
\hline
\end{tabular}

Table 7. Uncertainty in important parameters.

\begin{tabular}{lccc}
\hline$\Delta H_{\text {ads }}(\mathrm{kJ} / \mathrm{kg})$ & $C_{p}(\mathrm{~J} / \mathrm{kg} \mathrm{K})$ & $E_{a}(\mathrm{~kJ} / \mathrm{k} \mathrm{mol})$ & Adsorption capacity $(\mathrm{g} / \mathrm{kg})$ \\
\hline $910 \pm 1.288-1396 \pm 4.625$ & $507 \pm 7.2-1039 \pm 1.96$ & $1500 \pm 48$ & $71 \pm 18$ \\
\hline
\end{tabular}

reported values such as heat of adsorption, specific heat and activation energy of $\mathrm{CH}_{4}$ adsorbed, and adsorption capacity of the activated carbon are tabulated in table 7 .

\section{Conclusions}

From the experimental study the micropore characteristics of the locally available coconut shell based activated carbon (IndoCarb GC D612) are obtained. The pore volume and BET surface area are found to be quite high. From the isotherm and kinetics study the relevant parameters used in different isotherm models and kinetics are obtained. This data is essential for theoretical simulations and design of sorption systems based on this material. The study shows that the material considered here (IndoCarb GC D612) has lower storage capacity compared to AX21, which is also derived from coconut shell. However, compared to the imported AX21, IndoCarb GC D612 offers the advantages of low cost (less than $\$ 2$ per kg), easy availability, fast kinetics and reasonably high storage capacity. Hence it may be suitable for large scale storage applications, wherein the gravimetric storage capacity is not the most important requirement. Since the actual performance of the ANG depends on other aspects, such as heat and mass transfer effectiveness in addition to material characteristics, further studies are required on this material to establish its widespread use.

\section{Acknowledgement}

The authors sincerely thank ICC Indo German Carbons Limited, Kerala, for supplying the above-mentioned activated carbon sample along with some of its material properties.

\section{Nomenclature}

$a \quad$ instantaneous uptake $(\mathrm{kg} / \mathrm{kg})$

$a_{\mathrm{eq}} \quad$ equilibrium uptake $(\mathrm{kg} / \mathrm{kg})$

$C_{p, g} \quad$ specific heat of the gaseous phase $(\mathrm{kJ} / \mathrm{kg})$

$C_{p, a} \quad$ specific heat of the adsorbed phase $(\mathrm{kJ} / \mathrm{kg})$

$E \quad$ characteristic energy $(\mathrm{J} / \mathrm{mol})$

$E_{a}$ energy of activation $(\mathrm{J} / \mathrm{mol})$

$K_{\text {so }} \quad$ pre-exponent constant $\left(\mathrm{s}^{-1}\right)$

$K_{H} \quad$ Henry's constant $\left(\mathrm{MPa}^{-1}\right)$

$M \quad$ molecular weight $(\mathrm{kg} / \mathrm{kmol})$

$m_{\mathrm{s}} \quad$ mass of the adsorbent $(\mathrm{kg})$

$P \quad$ Pressure $(\mathrm{Pa})$

$R \quad$ gas constant $(\mathrm{kJ} /(\mathrm{kg} \mathrm{K}))$

$R_{u} \quad$ universal gas constant $(\mathrm{kJ} /(\mathrm{kmol} \mathrm{K}))$

$T$ temperature $(\mathrm{K})$

$V \quad$ volume $\left(\mathrm{m}^{3}\right)$

$v \quad$ specific volume $\left(\mathrm{m}^{3} / \mathrm{kg}\right)$

$W \quad$ volumetric adsorbate uptake $\left(\mathrm{m}^{3} / \mathrm{kg}\right)$ 
$W_{o}$ the limiting volumetric adsorbate uptake $\left(\mathrm{m}^{3} / \mathrm{kg}\right)$

Z compressibility factor

\section{Greek symbols}

$\begin{array}{ll}\tau & \text { time }(\mathrm{s}) \\ \Delta H_{\text {ads }} & \text { isosteric heat of adsorption }(\mathrm{kJ} / \mathrm{kg}) \\ \alpha & \text { thermal expansion coefficient }\left(\mathrm{K}^{-1}\right) \\ \rho & \text { density }\left(\mathrm{kg} / \mathrm{m}^{3}\right)\end{array}$

\section{Subscripts}

$\begin{array}{ll}\mathrm{a} & \text { adsorbed } \\ \mathrm{b} & \text { boiling } \\ \mathrm{cr} & \text { critical } \\ \mathrm{He} & \text { Helium } \\ \mathrm{Me} & \text { Methane } \\ \text { exp } & \text { experimental } \\ \text { pre } & \text { predicted } \\ \text { rea } & \text { reactor } \\ \text { sat } & \text { saturation } \\ \text { st } & \text { storage } \\ \mathrm{t} & \text { total }\end{array}$

\section{References}

[1] Wang X and Economides M J 2012 Purposefully built underground natural gas storage. J. Natural Gas Sci. Eng. 9: 130-137

[2] Biloe S, Goetz V and Mauran S 2001a Dynamic discharge and performance of a new adsorbent for natural gas storage. AIChE J. 47(12): 2819-2830

[3] Biloe S, Goetz V and Mauran S 2001b Characterization of adsorbent composite blocks for methane. Carbon 39(11): 1653-1662

[4] Chang K J and Talu O 1996 Behaviour and performance of adsorptive natural gas storage cylinders during discharge. Appl. Therm. Eng. 16(5): 359-374

[5] Cook T L, Komodromos C, Quinn D F and Ragan S 1999 Adsorbent storage for natural gas vehicles. In: Burchell T D (ed) Carbon material for advanced technologies. USA: Pergamon, pp. 269-302

[6] Mota J P B 2008 Adsorbed natural gas technology. Recent advances in adsorption processes for environmental protection and security. Netherlands: Springer, pp. 177-192

[7] Wegrzyn J and Gurevich M 1996 Adsorbent storage of natural gas. Appl. Energy 55(2): 71-83

[8] Choi B U, Choi D K, Lee Y W and Lee B K 2003 Adsorption equilibria of methane, ethane, ethylene, nitrogen and hydrogen onto activated carbon. J. Chem. Eng. Data 48(3): 603-607

[9] Frere M G and De Weireld G F 2002 High-pressure and high-temperature excess adsorption isotherm of $\mathrm{N}_{2}, \mathrm{CH}_{4}$, and $\mathrm{C}_{3} \mathrm{H}_{8}$ on activated carbon. J. Chem. Eng. Data 47(4): 823-829

[10] Himeno S, Komatsu T and Fujita S 2005 High-pressure adsorption equilibria of methane and carbon dioxide on several activated carbons. J. Chem. Eng. Data 50(2): 369-376

[11] Loh W S, Rahman K A, Chakraborty A, Saha B B, Choo Y S, Khoo B C and Ng K C 2010 Improved isotherm data for adsorption of methane on activated carbons. J. Chem. Eng. Data 55(8): 2840-2847

[12] Otowa T, Tanibata R and Itoh M 1993 production and adsorption characteristics of MAXSORB: High surface area active carbon, gas separation and purification. 7 (4): 241-245

[13] Sahoo P K, John M, Newalkar B L, Choudhary N V and Ayappa K G 2011 Filling characteristics for an activated carbon based adsorbed natural gas storage system, Ind. Eng. Chem. Res. 50(23): 13000-13011

[14] MacDonald J A F and Quinn D F 1998 Carbon adsorbents for natural gas storage. Fuel 77(1): 61-64

[15] Saha BB, EI-Sharkawy I, Habib K, Srinivasan K and Dutta P 2007 Evaluation of adsorption parameters and heats of adsorption through desorption measurement. J. Chem. Eng. Data 52(6): 2419-2424

[16] Seaton N A, Walton J P R B and Quirke 1989 A new analysis method for the determination of the pore size distribution of porous carbon from nitrogen adsorption measurements. Carbon 27(6): 853-861

[17] Wang X, French J, Kandadai S and Chua H T 2010 Adsorption measurements of methane on activated carbon in the temperature range (281-343) $\mathrm{K}$ and pressure to $1.2 \mathrm{MPa}$, J. Chem. Eng. Data 55(8): 2700-2706

[18] Ozawa S, Kusumi S and Ogino Y 1976 Physical adsorption of gases at high pressure. J. Colloid Interface Sci. 56(1): 83-91

[19] Glueckauf E and Coates JI 1947 The influence of incomplete equilibrium on front boundary of chromatograms and effectiveness of separation. J. Chem. Soc. 1315-1321

[20] Chihara K and Suzuki M 1983 Simulation of nonisothermal pressure swing adsorption. J. Chem. Eng. Jpn 16(1): 53-61

[21] Gemmingen U V 1993 Pressure swing adsorption processdesign and simulations. In: Suzuki M (ed) Proceedings of the fourth international conference on fundamentals of adsorption, Kyoto, Kodansha, Japan, pp. 703-712

[22] Hartzog D G and Sircar S 1995 Sensitivity of PSA process performance to input variables. Adsorption 1(2): 133-151

[23] Raghavan N S, Hassan M M and Ruthven D M 1986 Numerical simulation of PSA system using a pore diffusion model. Chem. Eng. Sci. 41(11): 2787-2793

[24] Vasiliev L L, Kanonchik L E, Mishkinis D A and Rabetsky M I 2000 Adosorbed natural gas storage and transportation vessels. Int. J. Therm. Sci. 39(9): 1047-1055

[25] Rahman K A, Chakraborty A, Saha B B and Ng K C 2012 On thermodynamics of methane + carbonaceous material adsorption. Int. J. Heat Mass Transfer 55(4): 565-573 